\title{
Positive Work: A Multidimensional Overview and Analysis of Work-Related Drivers of Wellbeing
}

\section{Tim Lomas ${ }^{1}$ (D)}

Accepted: 16 April 2019 / Published online: 22 May 2019

(C) Springer Nature Switzerland AG 2019

\begin{abstract}
Scholars are beginning to better appreciate the wide range of work-related 'drivers' of wellbeing (i.e., the ways in which work may promote or hinder employees' wellbeing). This paper brings a multidimensional perspective to bear on this topic by providing a multidimensional overview of these drivers, together with an analysis of how they may actually 'drive' wellbeing. The paper is in two parts. Part 1 briefly summarises the drivers, highlighting key theories and interventions. Part 2 then brings a multidimensional analysis to bear on the drivers, doing so by focusing on one driver in particular ('managing emotions') as a case study. This driver is analysed through the prism of a multidimensional model of the person (the Layered Integrated Framework Example). It is hoped that, in future, similar analyses can consequently be undertaken for the other drivers. The paper therefore offers a generative research agenda for exploring how to better enable people to flourish at work.
\end{abstract}

Keywords Engagement · Flourishing · Wellbeing · Positive organisational scholarship · Positive organisational behaviour

\section{Introduction}

Recent decades have seen an increasing focus on employee wellbeing, as reflected in the emergence of two new work-related academic paradigms, positive organizational behaviour (Luthans 2002) and positive organizational scholarship (Cameron et al. 2003). Although these two overlap considerably, Bakker and Schaufeli (2008) suggest the former is more 'organization-driven' (enhancing employee performance to benefit the organisation), whereas the latter is more 'employee-driven' (enhancing organisational performance to benefit employees). However, it is recognised that these perspectives are not necessarily

Tim Lomas

t.lomas@uel.ac.uk

1 Department of Psychology, University of East London, Stratford Campus, London E15 4LZ, UK 
oppositional, but can be synergistic, since organisations that value employee wellbeing as a substantive good may be more likely to thrive themselves (Zwetsloot and Pot 2004). As such, there is considerable overlap between the two paradigms; recognising this, we might refer to both together under the broader label of 'positive work.'

As a contribution to this burgeoning arena of scholarship, this paper focuses on the work-related 'drivers' of wellbeing (i.e., work-related factors that promote or hinder employee wellbeing). The paper has two main aims, namely to offer: (a) a brief multidimensional overview of these drivers; and (b) an illustrative multidimensional analysis of the drivers. The paper is thus in two main parts. Part 1 is the overview, reflecting the current state of the literature. This lays the groundwork for part 2, which shows what a multidimensional analysis of these drivers might look like - doing so by focusing on one driver in particular as a case study ('managing emotions') - thus outlining a future research agenda to further our understanding of these drivers.

In this process, the paper will strive to articulate a multidimensional appreciation of what work-related wellbeing looks like. In the literature, key constructs that pertain to work-related wellbeing include job satisfaction (Weiss 2002) and engagement (Bakker and Schaufeli 2008). This paper does lean on these two concepts in its understanding of work-related wellbeing, in that an employee who is engaged and satisfied with their work could be deemed to be experiencing work-related wellbeing. However, the paper also seeks to go beyond these more 'psychological' aspects of wellbeing, to incorporate other dimensions of the person. The key notion in the sentences above, and in this paper as a whole, is that of multidimensionality. Contemporary scholarship is increasingly appreciative of the multidimensional nature of wellbeing. This is not a new idea of course: it is evident, for example, in the World Health Organization's (1948) inclusive definition of health as 'a state of complete physical, mental and social well-being, and not merely the absence of disease and infirmity.' The three dimensions of health identified by the World Health Organization - mental/psychological, physical and social - can likewise be construed as dimensions of wellbeing; for instance, Pollard and Davidson (2001, p.19) define wellbeing as 'a state of successful performance across the life course integrating physical, cognitive and social-emotional function.' This definition could easily be used as an expansive definition of work-related wellbeing, for instance by inserting the phrase 'in work-related contexts' in the place of 'across the life course.'

However, multidimensionality can be taken still further, providing even greater detail in our understanding of the person and their wellbeing. To this end, this paper explores wellbeing at work through the prism of a new multidimensional framework known as the LIFE (Layered Integrated Framework Example) model (Lomas et al. 2015a). Following the pioneering work of the philosopher Ken Wilber (2000), in contrast to most other multidimensional models - such as the World Health Organization's - the LIFE model identifies four main ontological domains of the person. As per the World Health Organization definition, the model acknowledges the distinction between subjective 'mind' and objective 'body/brain' ('mental' and 'physical' in their terminology). However, as per Wilber, the LIFE model also separates the collective 'social' dimension into subjective (or 'intersubjective) and objective (or 'interobjective'). One might refer to the former as 'culture,' encompassing shared language, meanings, and worldviews. Conversely, the latter could be labelled 'society,' and denotes the material and structural scaffolding of these networks (e.g., the physical environment, or non-physical systems such as economic activity). 
It is worth noting that these dimensions appear to overlap with those of Demerouti et al.'s (2001) influential Job Demands-Resources model, in which work-related wellbeing is conceptualised as a function of the trade-offs between demands and resources. In that, resources are defined as "physical, psychological, social or organisational aspects of the job that may do one of the following: (a) be functional in achieving work goals; (b) reduce job demands and the associated physiological and psychological costs; (c) stimulate personal growth and development' (p.501). This definition arguably covers the same four dimensions of the LIFE model, namely 'physical [i.e., the body], psychological [i.e., the mind], social [i.e., culture] or organisational [i.e., society] aspects of the job.' However, the LIFE model provides further nuance to our multidimensional understanding of the person, and of their wellbeing, by stratifying the four dimensions into five layers/levels.

With its stratified layers, the LIFE model permits a more detailed multidimensional analysis than is offered by the Job Demands-Resources model (though this is not a critique of the latter; the LIFE model could simply be regarded as a complexification of this already successful framework). In the LIFE model, the mind is differentiated into embodied sensations, emotions, cognitions, conscious awareness, and 'awareness+' (advanced states of consciousness). The body is deconstructed into biochemistry, neurons, neural networks, the nervous system, and the body as a whole. Finally, culture and society are both stratified using Bronfenbrenner's (1977) ecological systems theory (microsystems, mesosystems, exosystems, macrosystems), plus an additional outer layer reflecting the global biosphere. Collectively, the model offers a meta-theoretical 'map' of the person, and of their wellbeing. Each level within each dimension encompasses the various 'aspects' of wellbeing, from the subjective (e.g., positive affect) to the objective (e.g., neurotransmitter levels) to the intersubjective (e.g. interpersonal trust) to the interobjective (e.g., network ties). This model can then be used to understand how work impacts upon wellbeing. Indeed, in part 2 of this paper, this model is presented as the basis for a future research agenda into the work-related drivers of wellbeing, exploring how these drivers impact upon the various dimensions and levels of the model, thereby 'driving' wellbeing. First though, we need to identify what the drivers are. As such, part 1 of the paper provides a brief overview of these drivers, drawing on current literature.

\section{A Multidimensional Overview of the Drivers of Wellbeing}

In order to identify the potential drivers of wellbeing, I consulted five taxonomies that are prominent in the literature. Firstly, the American Psychological Association's (1999) Psychologically Healthy Workplace Program, which rates good practice according to five categories: health and safety; work-life balance; employee involvement; employee development; and employee recognition. Secondly, Levering's (1988) influential Great Place to Work initiative, which assesses workplaces on: camaraderie; respect; credibility; fairness; and pride. Thirdly, Rego and Cunha's (2008) criteria for 'authentizotic' organisations: camaraderie; trust in/of the leader; open communication; opportunities for personal development; fairness; and work-life balance. Fourth, Crabb's (2011) analysis of the drivers of engagement, featuring three 'individual' drivers (focusing strengths; managing emotions; and aligning purpose), and four 'organizational' drivers 
(transparent leadership; employee 'voice'; organisational integrity; and reward and recognition). And finally, Sauter et al.'s (1990) six categories of resources/stressors: workload and work pace; role stressors; career concerns; scheduling; interpersonal relationships; and job content and control. I sought to identify commonalities among these criteria, and moreover align these with the dimensions of the LIFE model. It seemed reasonable to group the components of these taxonomies into 11 distinct drivers, 4 pertaining to the psychological dimension, 3 to the physical dimension, and 4 to the collective dimension (the social and cultural dimensions amalgamated together). These 11 drivers are briefly elucidated in the three sections below.

\subsection{Psychological Drivers of Wellbeing}

Four main psychological drivers were identified across the taxonomies above: focusing strengths; managing emotions; aligning purpose; and personal and professional development. Focusing strengths, identified by Crabb (2011), draws on the concept of 'character strengths,' pioneered by Peterson and Seligman (2004). In a work context, the basic premise is that work engagement is enhanced to the extent that people are able to deploy and cultivate their 'signature' strengths (i.e., those they value and excel at). Managing emotions, also identified by Crabb, encompasses concepts such as emotional intelligence (Salovey and Mayer 1990), emotion regulation (Gross 1999), and selfregulation (Baumeister and Vohs 2003), as well as more specific qualities like resilience (Reivich et al. 2011). The key point here is that work-related wellbeing is facilitated to the extent that employees are able to skilfully regulate their emotions (Nelis et al. 2009). Thirdly, aligning purpose, again in Crabb's taxonomy, refers to the importance of work being appraised as personally meaningful, such that it 'aligns' with one's own values/priorities. Finally, a fourth driver, personal and professional development, is introduced here as an amalgamation of the American Psychological Association's (1999) notion of employee development, Rego and Cunha's (2008) criterion of opportunities for personal development, and Sauter et al.'s (1990) category of career concerns. These four drivers are outlined in Table 1 below, together with key theories associated with that driver, and a range of indicative interventions designed to promote that driver in work settings (though please note that, in the table, the interventions do not map 1:1 on to the theories/model in the second column, i.e., the intervention listed does not necessarily pertain to the theory/model it happens to share a row with). The theories used to illustrate this driver (and the other drivers) were selected on the basis of prominence, being those that appeared to feature heavily in the literature consulted. The interventions were selected on the basis of being either prominent or otherwise particularly interesting or representative of the given driver, thus providing a sense of the possibilities in that area (Table 1).

\subsection{Physical Drivers of Wellbeing}

Three main physical drivers were identified across the taxonomies: health and safety; workload and scheduling; and job content and control. Health and safety, taken from the American Psychological Association's criteria (1999), is not only physically important annually there are an estimated 2 million work-related deaths worldwide (World Health Organization 2008) - but emotionally too, being a major risk factor for burnout (Nahrgang 
et al. 2011). The second main driver is labelled 'workload and scheduling,' an overarching category relating to the physical demands of work. This encompasses work-life balance (identified by the American Psychological Association, and Rego and Cunha 2008), together with Sauter et al.'s (1990) two categories of workload and work pace and scheduling. It also intersects with notions and practices such as work-home segmentation or integration (Clark 2000; Kreiner 2006). Concepts like work-life balance are not simply physical issues of course, but complex psychosocial ones; nevertheless, arguably work-life balance is fundamentally about the physical demands of work-e.g., how many hours it consumes-and so has been included here as a physical driver. Other scholars might prefer to categorise it as a sociocultural driver, which would also be a reasonable way of arranging this overarching taxonomy. Finally, the third driver is job content and control, also identified by Sauter et al. Again, some might regard this more as a psychosocial driver (e.g., as it involves factors like subjective perception of control). However, it is included here as a physical driver as it essentially covers what employees are required to $d o$ with their body/brain, i.e., the physical and neurophysiological demands of labour. These three drivers are outlined in Table 2 below, again with key theories associated with that driver, and indicative strategies designed to promote that driver in occupational settings (and once again, please note that the intervention listed does not necessarily pertain to the theory/model it happens to share a row with).

\subsection{Socio-Cultural Drivers of Wellbeing}

Finally, we come to the collective dimensions of the LIFE model, culture and society (as elucidated in more detail under the rubric of 'positive social psychology' [Lomas 2015]). These two dimensions are grouped together here, since the same drivers tend to be operative across both domains, manifesting with both an intersubective 'cultural' aspect and an interobjective 'societal' aspect. For instance, recognition and reward have both intersubjective features (e.g., respect from colleagues and leaders) and interobjective features (e.g., monetary recompense). Four socio-cultural drivers were identified: relationships; leadership; values; and reward and recognition. Together these create the 'psychological climate' of an organisation (Parker et al. 2003). The first driver, relationships, encompasses two of Levering's (1988) criteria (camaraderie and respect), two of Rego and Cunha's (2008) (camaraderie and open communication), and Sauter et al.'s (1990) category of interpersonal relationships. The second driver is leadership, which includes Crabb's (2011) 'organizational' driver of transparent leadership, Rego and Cunha's criteria of trust in/of the leader, and the American Psychological Association's (1999) notion of employee involvement. The third driver is values, derived from Crabb's taxonomy; although Crabb labelled this as 'organisational integrity,' it was felt here that values was a more overarching label, reflecting Peterson and Park's (2006, p.1152) notion of 'organisational-level virtues.' Finally, 'reward and reconition' was identified as an organisational level driver by Crabb; here it is used to also encompass Crabb's idea of employee voice, the American Psychological Association's notion of employee recognition, Levering's criteria of fairness and pride, and Rego and Cunha's category of fairness. These four drivers are outlined in Table 3 below, again with key theories associated with that driver, and indicative strategies designed to promote that driver in occupational settings (and again, please note that the intervention listed does not necessarily pertain to the theory/model it happens to share a row with). 
Table 1 Psychological drivers of wellbeing - indicative theories and interventions

\begin{tabular}{|c|c|c|}
\hline Driver & Theories/models & Interventions/initiatives \\
\hline \multirow[t]{4}{*}{ Strengths } & $\begin{array}{l}\text { Values-In-Action (Peterson and } \\
\text { Seligman 2004). }\end{array}$ & $\begin{array}{l}\text { Working for wellness program } \\
\text { (Page and Vella-Brodrick 2013). }\end{array}$ \\
\hline & Realise2 (Linley et al. 2009). & $\begin{array}{l}\text { Strengths-based coaching } \\
\text { (Coetzer et al. } 2014 .\end{array}$ \\
\hline & Strengths-Finder (Rath 2007). & $\begin{array}{l}\text { Signature-strengths intervention } \\
\text { programme (Forest et al. 2012). }\end{array}$ \\
\hline & & $\begin{array}{l}\text { Role-shaping, complimentary } \\
\text { partnering, and strengths-based } \\
\text { teamwork (Linley et al. 2009). }\end{array}$ \\
\hline \multirow[t]{6}{*}{ Managing emotions } & $\begin{array}{l}\text { Emotional intelligence } \\
\quad \text { (Salovey and Mayer 1990). }\end{array}$ & $\begin{array}{l}\text { Emotional Intelligence training } \\
\text { (Nelis et al. 2009). }\end{array}$ \\
\hline & Emotion regulation (Gross 1999). & PsyCap training (Luthans et al. 2010. \\
\hline & $\begin{array}{l}\text { Self-regulation (Baumeister } \\
\text { and Vohs 2003). }\end{array}$ & $\begin{array}{l}\text { Master Resilience Training } \\
\text { (Reivich et al. 2011). }\end{array}$ \\
\hline & Resilience (Reivich et al. 2011). & Mindfulness-based interventions \\
\hline & PsyCap (Luthans et al. 2007). & (Kabat-Zinn 2003). \\
\hline & Mindfulness (Kabat-Zinn 2003). & \\
\hline \multirow[t]{4}{*}{ Aligning purpose } & Meaning in work (Steger et al. 2012. & Career counselling (Dik et al. 2009. \\
\hline & Work-related values (Persson et al. 2001). & Job crafting (Wrzesniewski 2003). \\
\hline & Work orientations (Bellah et al. 1996). & $\begin{array}{l}\text { Meaning-centred interventions } \\
\text { (Fillion et al. 2009). }\end{array}$ \\
\hline & Work identities (Dutton et al. 2010). & $\begin{array}{l}\text { Career education interventions } \\
\text { (Dik et al. 2011). }\end{array}$ \\
\hline \multirow[t]{5}{*}{$\begin{array}{l}\text { Personal and professional } \\
\text { development }\end{array}$} & Career development (Super 1980). & $\begin{array}{l}\text { Work-based self-determination } \\
\text { intervention (Deci et al. 1989). }\end{array}$ \\
\hline & Ego development (Cook-Greuter 2000). & $\begin{array}{l}\text { Continuous improvement } \\
\text { programmes } \\
\text { (Schroeder and Robinson 2002). }\end{array}$ \\
\hline & Cognitive development (Rogoff 1990). & $\begin{array}{l}\text { Vocational interventions } \\
\text { (Giordano 1995). }\end{array}$ \\
\hline & Moral development (Kohlberg 1981). & Skills training, e.g., writing \\
\hline & Psychological wellbeing (Ryff 1989). & \\
\hline
\end{tabular}

\section{A Multidimensional Analysis - Managing Emotions as a Case Study}

Having provided a brief overview of the work-related drivers of wellbeing, this second part illustrates what a multidimensional analysis of these drivers might look like. This illustration could then serve as the basis of a future research agenda into the drivers. In turn, such research could help inform the promotion of wellbeing in occupational contexts, which is increasingly recognised as an important policy goal (Daniels et al. 2012), as considered further below. Specifically, the stratified layers of the LIFE model can be used to investigate the drivers in some depth (in a more fine-grained way than is encouraged by non-stratified multidimensional frameworks such as Demerouti et al.'s 
Table 2 Physical drivers of wellbeing - indicative theories and interventions

\begin{tabular}{|c|c|c|}
\hline Driver & Theories/models & Interventions/initiatives \\
\hline \multirow[t]{5}{*}{ Health and safety } & Work safety (Hayes et al. 1998). & $\begin{array}{l}\text { Educational training } \\
\quad \text { (Daltroy et al. 1997). }\end{array}$ \\
\hline & $\begin{array}{l}\text { Muskuloskeletal disorders } \\
\text { (Kennedy et al. 2010). }\end{array}$ & $\begin{array}{l}\text { Exercise/stretching programmes } \\
\text { (da Costa and Vieira 2008). }\end{array}$ \\
\hline & Air quality (Satish et al. 2012). & $\begin{array}{l}\text { Ergonomic design } \\
\quad \text { (Brewer et al. 2006). }\end{array}$ \\
\hline & $\begin{array}{l}\text { Thermal comfort (Ormandy } \\
\text { and Ezratty 2012). }\end{array}$ & $\begin{array}{l}\text { Safety-based supervisory } \\
\text { monitoring (Zohar and Luria 2003). }\end{array}$ \\
\hline & Noise levels (Basner et al. 2014). & $\begin{array}{l}\text { Safety management by walking } \\
\text { around (Luria and Morag 2012). }\end{array}$ \\
\hline \multirow[t]{4}{*}{$\begin{array}{l}\text { Workload and } \\
\text { scheduling }\end{array}$} & $\begin{array}{l}\text { Occupational fatigue } \\
\text { (Winwood et al. 2005). }\end{array}$ & $\begin{array}{l}\text { Regulation, e.g., European Working } \\
\text { Time Directive (Health and Safety } \\
\text { Executive 1998). }\end{array}$ \\
\hline & Shift rotation (Tucker et al. 1998. & $\begin{array}{l}\text { Flexible scheduling initiatives } \\
\text { (Kandolin and Huida 1996). }\end{array}$ \\
\hline & Recovery strategies, e.g., & Open-rota systems (Pryce et al. 2006). \\
\hline & $\begin{array}{l}\text { psychological detachment from } \\
\text { work (Moreno-Jiménez et al. 2009). }\end{array}$ & $\begin{array}{l}\text { Work-life balance interventions } \\
\text { (Rupashree and Shivganesh 2010). }\end{array}$ \\
\hline \multirow[t]{5}{*}{$\begin{array}{l}\text { Job content and } \\
\text { control }\end{array}$} & $\begin{array}{l}\text { Quality of work (van der Doef } \\
\text { and Maes 1999). }\end{array}$ & $\begin{array}{l}\text { Work-reorganisation interventions } \\
\text { (Bond et al. 2008). }\end{array}$ \\
\hline & $\begin{array}{l}\text { Physical labour (Williams and } \\
\text { Sambrook 2011). }\end{array}$ & $\begin{array}{l}\text { Control-enhancing stress-reduction } \\
\text { intervention (Logan and } \\
\text { Ganster 2005). }\end{array}$ \\
\hline & $\begin{array}{l}\text { Varied versus repetitive content } \\
\quad \text { (Sauter et al. 1990) }\end{array}$ & $\begin{array}{l}\text { Job control burnout prevention } \\
\text { (Hätinen et al. 2007). }\end{array}$ \\
\hline & $\begin{array}{l}\text { Self-regulation at work } \\
\quad \text { (Pomaki and Maes 2002). }\end{array}$ & $\begin{array}{l}\text { Task-restructuring interventions } \\
\text { (Bambra et al. 2007). }\end{array}$ \\
\hline & $\begin{array}{l}\text { Self-efficacy (Stajkovic and } \\
\text { Luthans 1998). }\end{array}$ & \\
\hline
\end{tabular}

2001 Job Demands-Resources model). The essential premise of this research agenda is that each driver, while being primarily situated in one of the dimensions of the LIFE model, will also impact upon, and be impacted by, all the dimensions and levels of the model. That is, it is envisaged that every driver manifests at all these dimensions and levels, each of which accounts for an aspect of the way the driver affects wellbeing.

Take for example the driver 'managing emotions' (ME). While evidently 'about' emotions, it does not only concern emotions. It will have manifestations at multiple levels of the mind, with embodied, affective, cognitive, conscious, and even spiritual components. Moreover, as per the 'neural correlates of consciousness' paradigm (Fell 2004), this driver will also supervene upon multiple levels of the body/brain, i.e., it depends upon complex physiological substrates, from biochemical processes to the nervous system as a whole. Furthermore, it will affect, and be affected by, socio-cultural processes at all levels of scale, from microsystems to macrosystems. An analysis along these lines will enable us to explore exactly how these drivers affect wellbeing, asking questions like: (a) what are the 
causal mechanisms by which they enhance wellbeing; (b) what conditions enhance or impede their effectiveness; (c) how can workplaces, and applied interventions, best be designed to promote these drivers; and (d) are such initiatives/interventions cost-effective?

This second part then illustrates how this kind of analysis might work. It is beyond the scope of this paper to do this for all the drivers. Instead, I will just focus on the ME driver as a case study to show what such analyses might reveal. Future work could then undertake similar analyses for all the other drivers. Before setting out, it is worth mentioning that particular attention will be paid here to research and interventions pertaining to mindfulness. Mindfulness is a label given to both a meditative practice designed to train attention and awareness, and to the state that such practice is intended to inculcate, defined as 'the awareness that arises through paying attention on purpose, in the present moment, and nonjudgementally to the unfolding of experience moment by moment' (Kabat-Zinn 2003,

Table 3 Socio-cultural drivers of wellbeing - indicative theories and interventions

\begin{tabular}{|c|c|c|}
\hline Driver & Theories/models & Interventions/initiatives \\
\hline \multirow[t]{2}{*}{ Relationships } & $\begin{array}{l}\text { Social capital (Bourdieu 1986). } \\
\text { Perceived social support } \\
\quad \text { (Zimet et al. 1988). }\end{array}$ & $\begin{array}{l}\text { Communication training programmes } \\
\text { (Kruijver et al. 2000). }\end{array}$ \\
\hline & $\begin{array}{l}\text { Social network analysis } \\
\text { (Cross et al. 2002). }\end{array}$ & $\begin{array}{l}\text { Civility interventions } \\
\text { (Leiter et al. 2011). } \\
\text { Loving-Kindness Meditation } \\
\text { (Fredrickson et al. 2008). } \\
\text { Mediation (Ridley-Duff and } \\
\text { Bennett 2011). }\end{array}$ \\
\hline \multirow[t]{3}{*}{ Leadership } & $\begin{array}{l}\text { Charismatic leadership (House 1977). } \\
\text { Transformational leadership } \\
\text { (Bass 1991). } \\
\text { Spiritual leadership (Fry 2003). }\end{array}$ & $\begin{array}{l}\text { Executive coaching (Thach 2002). } \\
\text { Management by walking around } \\
\text { (Rubin and Stone 2010). }\end{array}$ \\
\hline & $\begin{array}{l}\text { Distributed leadership (Gronn 2000). } \\
\text { Ethical leadership (Brown et al. 2005). }\end{array}$ & $\begin{array}{l}\text { Supervisory quality interventions } \\
\text { (Wagner et al. 2015). }\end{array}$ \\
\hline & $\begin{array}{l}\text { Authentic leadership } \\
\quad \text { (Avolio and Gardner 2005). } \\
\text { Leader-member social exchange } \\
\quad \text { (Bernerth et al. 2007). }\end{array}$ & $\begin{array}{l}\text { Managerial leadership development } \\
\text { programmes (Collins and Holton 2004). }\end{array}$ \\
\hline \multirow[t]{3}{*}{ Values } & $\begin{array}{l}\text { Spiral dynamics (Beck and } \\
\text { Cowan 1996). }\end{array}$ & $\begin{array}{l}\text { Appreciative Inquiry (Cooperrider and } \\
\text { Srivastva 1987). }\end{array}$ \\
\hline & $\begin{array}{l}\text { Authentizotic organisations } \\
\text { (Kets de Vries 2001). }\end{array}$ & $\begin{array}{l}\text { Spiral dynamics interventions } \\
\text { (Robinson and Harvey 2008). }\end{array}$ \\
\hline & $\begin{array}{l}\text { Corporate social responsibility } \\
\text { (Garriga and Melé 2004). }\end{array}$ & $\begin{array}{l}\text { Corporate ethics training programmes } \\
\text { (Delaney and Sockell 1992). }\end{array}$ \\
\hline \multirow[t]{3}{*}{$\begin{array}{l}\text { Reward and } \\
\text { recognition }\end{array}$} & $\begin{array}{l}\text { Procedural fairness (De Cremer } \\
\text { et al. 2005). }\end{array}$ & $\begin{array}{l}\text { Employee financial participation } \\
\text { (Morris et al. 2006). }\end{array}$ \\
\hline & $\begin{array}{l}\text { Organisation-based self-esteem } \\
\text { (Bowling et al. 2010). }\end{array}$ & $\begin{array}{l}\text { Collective performance rewards } \\
\text { (Bartol and Srivastava 2002). }\end{array}$ \\
\hline & & $\begin{array}{l}\text { Non-financial recognition schemes } \\
\quad \text { (Silverman 2004) }\end{array}$ \\
\hline
\end{tabular}


p.145). Mindful awareness is not only strongly linked to the development of emotional management capacities, but is a fundamental component of these capacities (Chambers et al. 2009). However, a more specific reason for focusing on mindfulness here is that it is one of the most extensively tested interventions of its type, featuring analyses across numerous levels of the LIFE model. As such, it is a forerunner for the type of detailed multidimensional analyses that might in future be applied to other interventions (across all drivers). So, with that in mind, we'll proceed through the dimensions and levels of the LIFE model, exploring the way ME has been analysed in an occupational context thus far, and making recommendations for future research. As per part 1, we shall look in turn at the psychological, physical, and socio-cultural dimensions.

\subsection{The Psychological Dimension}

In the LIFE model, the psychological dimension is stratified into five layers: embodiment, emotion, cognition, consciousness, and awareness+. These are listed in Table 4 below, which includes examples of existing work pertaining to each level, together with suggestions for future research. The levels shall be considered in turn.

\subsubsection{Embodiment}

We begin with embodiment, the 'subjectivity of the lived body' (Turner 2001, p.253). As with all levels here, we shall be exploring what relevance this has to ME, the driver we are focusing on in this second part of the paper. In particular, we are interested in why and how ME 'drives' wellbeing, and whether this is partly related to processes at this specific level. And, it does appear that one of the ways ME enhances wellbeing is through its impact upon embodiment processes, such as body awareness: for instance, research suggests that emotional awareness techniques like mindfulness can enhance body awareness (Silverstein et al. 2011), and that such awareness in turn is associated with wellbeing (Brani et al. 2014). Beyond any generalised benefits that body awareness may have for wellbeing, it also has specific relevance to the workplace; for example, embodied awareness training is a component of self-management programmes that can help adults with chronic pain return to work sooner and function more adaptively in the workplace (Shaw et al. 2012). Beyond the benefits to such adults themselves, given the economic burden of chronic pain - a systematic review by Patel et al. (2012) found it diminished workplace productivity by up to $51 \%$ - interventions to redress chronic pain can therefore potentially be cost-effective (Loisel et al. 2002). (As discussed further below, a key task in relation to employee wellbeing is convincing organisations that the implementation of wellbeing interventions is worth it to them.) On a more general point, one can see how ME intersects with the other drivers of wellbeing, such as health and safety. Such considerations will be a common thread here, as part of the value of the LIFE model lies in showing how the drivers themselves impact upon each other.

\subsubsection{Emotions}

The relevance of this level to ME barely needs spelling out, as this driver is essentially of this level. Nevertheless, it is still worth highlighting the importance of employees being able to manage their emotions. Resilience, for example, is an important buffer of work-related stress, reducing the risk of burnout (Jackson et al. 2007). Moreover, we are seeing the 
Table 4 Examples of current and future psychological research (pertaining to managing emotions)

\begin{tabular}{|c|c|}
\hline Level & Existing research \\
\hline \multirow[t]{3}{*}{ Embodiment } & $\begin{array}{l}\text { Association between emotional and } \\
\text { interoceptive awareness } \\
\text { (Herbert et al. 2011). }\end{array}$ \\
\hline & $\begin{array}{l}\text { Impact of body awareness on subjectiv } \\
\text { wellbeing (Mehling et al. 2009). }\end{array}$ \\
\hline & $\begin{array}{l}\text { Psychomotor physiotherapy } \\
\text { (Dragesund and Råheim 2008). }\end{array}$ \\
\hline \multirow[t]{4}{*}{ Emotion } & $\begin{array}{l}\text { Emotional intelligence training } \\
\text { (Nelis et al. 2009). }\end{array}$ \\
\hline & PsyCap training (Luthans et al. 2010). \\
\hline & $\begin{array}{l}\text { Master Resilience Training } \\
\text { (Reivich et al. 2011). }\end{array}$ \\
\hline & $\begin{array}{l}\text { Analysis of impact of mindfulness } \\
\text { on emotional intelligence } \\
\text { (Lomas et al. 2014). }\end{array}$ \\
\hline \multirow[t]{3}{*}{ Cognition } & $\begin{array}{l}\text { Analysis of the cognitive components } \\
\text { of job satisfaction (Weiss 2002). }\end{array}$ \\
\hline & $\begin{array}{l}\text { Adverse impact of emotion regulation } \\
\text { on other cognitive processes } \\
\text { (Schmeichel 2007) }\end{array}$ \\
\hline & $\begin{array}{l}\text { The role of discursive cognitions in } \\
\text { emotional capacities like resilience } \\
\text { (Reivich et al. 2011). }\end{array}$ \\
\hline
\end{tabular}

Consciousness Impact of mindfulness on employee distress (Virgili 2015).

Impact of mindfulness on work relationships and performance (Good et al. 2015).

Mindful awareness as 'meta-skill' that affects multiple aspects of wellbeing (Brown et al. 2007)

Awareness+ Impact of flow on work engagement (Reid 2011).

Factors that facilitate flow states (Fullagar \& Kelloway, 2009).

The importance of spirituality in helping professions, e.g., nursing (Grant 2004).

Future research

Cost-benefit analyses of the impact of body-awareness training on injury, health, and absenteeism.

Relationship between emotional intelligence, workplace physicality (e.g., sitting posture), and work-place injury.

Randomised controlled trials comparing emotion-based interventions (e.g., Master Resilience Training vs. PsyCap).

Cost-effectiveness analyses of emotion-based interventions (e.g., Master Resilience Training).

Impact of socio-cultural drivers (e.g., leadership support) upon the effectiveness of mindfulness-based interventions.

Impact of emotional intelligence training on discursive cognitions.

Role of narrative restructuring (e.g., recalling positive events) in emotion regulation.

Large-scale randomised controlled trials of mindfulness-based interventions in the workplace, featuring outcomes such as wellbeing, health, and job performance.

Analysis of the efficacy of 'second generation' mindfulness-based interventions (which explicitly draw on Buddhist theory and practice) against that of 'first generation' mindfulness-based interventions (which are usually secular).

Factors that engender spirituality in the workplace, and its impact (e.g., in term of work being meaningful).

Working conditions that enable people to experience a flow state, and the impact that such states have on wellbeing.

emergence of interventions and initiatives to help inculcate resilience among employees. Reivich et al.'s (2011) Master Resilience Training programme has been widely implemented in the United States military - as part of its more general 'Ready and Resilient' initiative with promising results (e.g., as a protective factor against mental health issues [Elbogen 
et al. 2014]). With the increasing prevalence of such programmes - and an emergent consensus around their usefulness (Robertson et al. 2015) - research is beginning to focus on cost-effectiveness, as led by organisations like the Work Foundation (www. theworkfoundation.com). Similarly, there are increasingly calls from bodies, such as the Chartered Institute of Personnel and Development (2011b), for organisations to promote resiliency among their workforce. This latter point highlights an important consideration about the way different levels of the LIFE model intersect: policy-driven organisational provision of initiatives like resilience training reflects the impact of socio-cultural processes (at a micro-, meso-, exo- and macrosystem level), as discussed further in the third section below. This point likewise highlights the way the drivers themselves intersect, since the instantiation of such interventions depends on socio-cultural drivers such as values (i.e., an organisation-level concern with the welfare of its employees) and leadership (i.e., leaders who are committed to upholding these values).

\subsubsection{Cognition}

Cognition encompasses cognitive processes (e.g., memory) and discursive 'cognitions' (e.g., thoughts). This level is closely intertwined with ME: indeed, emotions and cognitions exert a bi-directional influence over each other. On one hand, discursive patterns influence emotions. For example, Reivich et al.'s (2011) Master Resilience Training is based in part on Beck et al.'s (1979) cognitive theory of mental disorder, particularly on the 'ABC' model of explanatory styles (in which the potential for an adverse Activating event to have negative emotional Consequences is a function of a person's Beliefs about that event). Thus emotional management can involve people 'working with' their cognitions. Similarly, discursive feedback (e.g., of job performance) in occupational settings can assist employees in their 'emotional labour,' which in turn affects wellbeing (Holman et al. 2002). From the other direction, ME can impact upon cognitions. Job satisfaction - a construct which incorporates cognitive components, such as beliefs about work, and evaulative judgements (Weiss 2002) - can be enhanced through emotional management skills, such as the ability to amplify pleasant emotions (Côté and Morgan 2002). There is also work on the association between emotion management and cognitive processes like memory: illustrating a 'limited resource' model of executive control, Schmeichel (2007) found that the effortful regulation of emotion adversely affected other cognitive processes. Such research reminds us that the drivers of wellbeing may not be uniformly positive in their effects. Analyses of such complexities is of course an important part of any future research agenda.

\subsubsection{Consciousness}

In the LIFE model, consciousness essentially refers to conscious awareness, a key component of ME. In Salovey and Mayer's (1990) hierarchical emotional intelligence model, emotional awareness is the foundational level (followed by generation, understanding, and management). It is likewise integral to Gross's (1999) concept of emotion regulation (Barrett et al. 2001). Given the importance of awareness, and also the recognition that it can be trained, there is increasing attention on initiatives to foster awareness in the workplace. Much of this has focused on mindfulness, arguably the exemplar intervention in this respect see Lomas et al. [2017a, 2017b, 2018a, 2018b, 2018c] for a series of systematic reviews and meta-analyses of this literature). For 
instance, a meta-analysis of mindfulness-based interventions in the workplace found it to be effective at reducing employee distress (Virgili 2015). Similarly, Good et al. (2015) found such interventions to be positively associated with the other drivers of wellbeing, like good working relationships, as well as overall job performance. Such is the burgeoning recognition of the value of mindfulness that its use is being increasingly advocated at a policy level, not only by individual companies (i.e., at a microsystem level), but by broader exosystem organisations like the National Health Service (NHS) in the United Kingdom (2015), and even at a macro-systemic governmental level. With the latter, a landmark report entitled 'Mindful Nation' was recently published by the Mindfulness All-Party Parliamentary Group (2015). It made policy recommendations in four key areas (health, education, criminal justice, and work). Regarding work, its recommendations were: (a) the Department for Business, Innovation and Skills work with employers to promote the use of mindfulness; (b) the What Works Centre for Wellbeing to commission, as a priority, high quality research into mindfulness in the workplace; (c) government departments to encourage the use of mindfulness-based interventions in the public sector; and (d) the National Institute of Health Research to invite bids on mindfulness as an occupational health intervention. This kind of policy-level advocacy will be discussed further below.

\subsubsection{Awareness+}

Finally, awareness+ is a catch-all term encompassing the nebulous idea of 'higher' states of mind (i.e., that are 'qualitatively different' from normal waking consciousness). These range from states of absorption or self-transcendence (Lomas, 2015b), to more esoteric psychospiritual experiences, like non-dual awareness (in which the standard subject-object dichotomy is transcended). In terms of ME, one might perhaps regard these states of mind as the 'strongest' product of advanced emotion regulation skills (e.g., non-dual awareness is generally regarded as a product of years of intensive meditation practice [Josipovic 2010]). Awareness+ also includes emotionally charged spiritual experiences which can be the result of emotionally-focused practices such as prayer. There has been relatively little enquiry into these kinds of elevated experiences in occupational settings. One exception is Csikszentmihalyi's (1990) concept of flow, a state of being 'in the zone' that arises when a person's attention is captivated by a challenging task, which has been linked to work engagement (Reid 2011). Another emergent line of enquiry is the role of spiritual practices (e.g., prayer) in the helping professions, like nursing (Koenig 2013), which some professionals find to be a helpful coping resource (Grant 2004). It will be interesting to see further research into these more elevated states.

\subsection{The Physical Dimension}

The physical dimension is stratified into five emergent layers: biochemistry, neurons, neural networks, nervous system, and the body as a whole. These are listed in Table 5 below, which includes examples of existing work pertaining to each level, together with suggestions for future research. The levels shall be introduced in turn (with neurons and neural networks considered together). 


\subsubsection{Biochemistry}

In the LIFE model, the foundational level is biochemistry, a catch-all term for all subcellular physiological processes. This would include, for instance, biomarkers of wellbeing, from cortisol to serotonin. Analyses of such biomarkers can provide useful information regarding the physiological causal mechanisms through which the drivers of wellbeing exert a positive impact. ${ }^{1}$ In the work arena, biochemical analyses include research into the impact of work factors on biomarkers like cortisol. For instance, Schulz et al. (1998) found elevated post-awakening cortisol in participants who were chronically stressed due to overwork (thus showing the impact of the physical driver of workload and scheduling). We are starting to see work focusing specifically on ME: examining elite athletes, Laborde et al. (2014) found that trait emotional intelligence predicted cortisol levels. Similarly, from an applied perspective, there are emergent studies exploring the biochemical impact of interventions like mindfulness: Malarkey et al. (2013) developed a 'low dose' mindfulness-based intervention for use in occupational settings, which appeared to lower cortisol levels in a clinically significant way (although the researchers urged further work to clarify this effect).

\subsubsection{Neurons and Neural Networks}

In the LIFE model, neurons and neural networks constitute separate conceptual levels, being at different levels of scale; however, since most mental operations arise from the dynamic interaction of neural populations across different brain areas, it makes sense to consider them together here. The field of 'affective neuroscience' (Davidson 2003) is beginning to make strides in understanding the neurophysiological substrates of emotion, including the 'neural correlates of wellbeing' (Urry et al. 2004). This is exemplified by the use of technologies like functional magnetic resonance imaging to connect the activation of particular brain regions to mental processes that are relevant in wellbeing (Lomas et al. 2015b). For instance, the type of executive cognitive control that is associated with emotional management has been linked to activation of the prefrontal cortex and anterior cingulate cortex (Newberg and Iversen 2003). Such research is beginning to be conducted in occupational settings, including in relation to ME. In a randomised controlled trial of a mindfulness-based intervention delivered to employees, Davidson et al. (2003) found a significant pre-post increase in relative leftsided hemispheric activation - a pattern associated with wellbeing - in the experimental group (while the intervention also appeared to positively affect immune function). More recently, Haase et al. (2015) explored the impact of mindfulness training on neural processing in elite athletes, linking this to outcomes such as increased activation of the anterior cingulate cortex (a brain region implicated in executive attention). Such research is in its infancy, and is an exciting area for future studies to explore.

\footnotetext{
$\overline{1}$ (We must be careful with the word 'causal' though. In charting the relationship between mental states (e.g., subjective wellbeing) and brain states (e.g., serotonin), the dominant paradigm in this area - the "neural correlates of consciousness' approach (Fell 2004) - cautions against assigning directional causality. That is, it may be a category error to assert that brain states cause mental states; it is possibly more accurate to say that a mental state of stress is caused by a psychosocial stressor, and that neurophysiological brain states are the mechanism through which such change is effected and manifested.)
} 
Table 5 Examples of current and future physiological research (pertaining to managing emotions)

\begin{tabular}{|c|c|c|}
\hline Level & Existing research & Future research \\
\hline Biochemistry & $\begin{array}{l}\text { Cortisol levels associated with trait emotional } \\
\text { intelligence (Laborde et al. 2014). } \\
\text { Impact of mindfulness training on cortisol } \\
\quad \text { (Malarkey et al. 2013). } \\
\text { Impact of mindfulness on immune system } \\
\text { functioning (Davidson et al. 2003). }\end{array}$ & $\begin{array}{l}\text { Relationship between length of mindfulness } \\
\text { training and cortisol. } \\
\text { Impact of emotional intelligence training on } \\
\text { neurotransmitter levels (e.g., serotonin). } \\
\text { Genetically-influenced susceptibility to } \\
\text { psychological interventions. }\end{array}$ \\
\hline $\begin{array}{c}\text { Neurons \& } \\
\text { neural } \\
\text { networks }\end{array}$ & $\begin{array}{l}\text { Role of the prefrontal cortex and anterior } \\
\text { cingulate cortex in executive attention } \\
\text { (Newberg and Iversen 2003). } \\
\text { Impact of mindfulness of left-sided hemi- } \\
\text { spheric activation (Davidson et al. 2003). } \\
\text { Impact of mindfulness on neural processing } \\
\text { (Haase et al. 2015). }\end{array}$ & $\begin{array}{l}\text { Impact of emotional intelligence training on } \\
\text { prefrontal cortex and anterior cingulate } \\
\text { cortex. } \\
\text { Role of mirror neurons in empathy (and the } \\
\text { training of empathic responses). } \\
\text { Impact of emotion-based interventions on } \\
\text { relative left-sided hemispheric activation. }\end{array}$ \\
\hline $\begin{array}{l}\text { Nervous } \\
\text { system }\end{array}$ & $\begin{array}{l}\text { Impact of stress-reduction programmes on } \\
\text { blood pressure (McCraty et al. 2003). } \\
\text { Impact of emotion-regulation strategies on } \\
\text { cardiovascular risk (Appleton et al. 2014). }\end{array}$ & $\begin{array}{l}\text { Impact of emotional intelligence training on } \\
\text { biomarkers (e.g., heart-rate variability), in- } \\
\text { cluding in response to specific work } \\
\text { stressors. } \\
\text { Viability of biofeedback programmes in the } \\
\text { workplace, and analysis of their impact on } \\
\text { biomarkers. }\end{array}$ \\
\hline Body & $\begin{array}{l}\text { Emotional intelligence lessens health-risk be- } \\
\text { haviours (Lana et al. 2015). } \\
\text { Emotional intelligence associated with } \\
\text { health-related quality of life (Gourzoulidis } \\
\text { et al. 2014). }\end{array}$ & $\begin{array}{l}\text { Impact of mindfulness and emotional } \\
\text { intelligence on health-related work behav- } \\
\text { iours (e.g., adaptive use of the body, or } \\
\text { avoidance of risk). } \\
\text { Association between mindfulness and take-up } \\
\text { of work-based health initiatives (e.g., exer- } \\
\text { cise programmes). }\end{array}$ \\
\hline
\end{tabular}

\subsubsection{Nervous System}

Moving up to the more encompassing level of the nervous system, investigation of outcomes associated with this has long been a feature of occupational research. Indeed, over 100 years ago, Hayhurst (1915) explored the impact of occupational strain on outcomes like cardiac functioning. Today there are a wealth of studies analysing nervous system outcomes, particularly in relation to the physical drivers of wellbeing, such as the association between job control and blood pressure (McCarthy et al. 2014), or between shift-work exposure (an aspect of workload and scheduling) and heart-rate variability (a biomarker of physical and mental health) (Bernardes Souza et al. 2014). There is an emergent literature on the impact of ME on such outcomes, indicating that action at this level is one of the ways that ME 'drives' wellbeing. For instance, Appleton et al. (2014) observed that emotion regulation strategies were differentially associated with cardiovascular disease risk - reappraisal strategies had a $5.9 \%$ lower risk, and suppression a $10 \%$ higher risk - suggesting that effective emotion regulation may promote cardiovascular health. These kinds of analyses are beginning to be conducted in work settings. A randomised controlled trial by McCraty et al. (2003) 
found that a work-based stress management programme - featuring emotional restructuring/refocusing techniques - lowered systolic blood pressure in a hypertensive experimental group, a reduction which also correlated with reduced stress symptoms.

\subsubsection{The Body}

The final level here is the body 'as a whole,' encompassing all aspects of physical function (that aren't specifically accounted for by the preceding layers). This would include research on work-related health generally. The literature is replete with analyses of the impact of occupational factors on health, like the effect of health and safety factors on issues such as musculoskeletal functioning (Daltroy et al. 1997) and morbidity and mortality (World Health Organization 2008). Of particular relevance here, from the perspective of our case study, are indications that ME can positively affect physical health. Analysing Belgian adults, Mikolajczak (2014) reports that emotional intelligence was a significant predictor of numerous health indicators (from smoking to healthcare use), over and above more conventional health predictors like social support. We are consequently beginning to see research on the health impact of ME undertaken in work-related settings. For instance, examining hospital managers in Greece, Gourzoulidis et al. (2014) found that emotional intelligence was associated with health-related quality of life. Explanations for the positive impact of ME on health range from the notion that emotional intelligence enables people to deal with workrelated stress more efficiently (as Karimi et al. (2015) found with Australian nurses), to the idea that emotional intelligence means people are less likely to take health risks (as Lana et al. (2015) observed with Spanish nursing students). It is thus increasingly recognised at a policy level that emotion management interventions can play an important role in public health, including in the workplace (Hahn and Truman 2015).

\subsection{The Socio-Cultural Dimensions}

Finally, we turn to the socio-cultural dimensions of the LIFE model. These are both stratified into five layers of increasing span: microsystem, mesosystem, exosystem, macrosystem and ecosystem. These are listed in Table 6 below, which includes examples of existing work pertaining to each level, together with suggestions for future research. The levels will be considered in turn.

\subsubsection{Microsystem}

The notion of the microsystem is taken from Bronfenbrenner (1977), as are the mesosystem, exosystem and macrosystem. Essentially, the microsystem is the immediate social context of the person, which in occupational terms would be their workplace and/or the organisation they work for. In terms of ME, this has a bidirectional relationship with the microsystem; we can thus explore the impact of ME on the microsystem, and vice versa. With the former, there is a growing literature on the positive impact of ME on the intersubjective culture of the microsystem; essentially, this work suggests that the development of emotional management capacities has a positive impact on workplace relationships (one of the socio-cultural drivers of wellbeing). For instance, a randomised controlled trial of a meditation-based 
intervention to cultivate 'loving-kindness' improved relationships among colleagues (Fredrickson et al. 2008). Conversely, we can also consider the impact of the microsystem on ME. Here we find that the socio-cultural drivers of wellbeing particularly values and leadership - are important factors in the extent to which employees are empowered to manage their emotions. For instance, as helpful as emotional management interventions are, these are unlikely to be instantiated in the first place unless employee wellbeing is valued by the organisation and its leaders. It is for this reason that policy-makers recognise the importance of convincing leaders of the merits of such initiatives - as recognised in the recent Mindful Nation (2015) report so that these can be implemented systemically at a micosystem level. (In turn, advocates of practices like mindfulness appreciate the importance of also convincing policymakers themselves, so that they are motivated to exert their macrosystemic influence on business in the first place.)

Table 6 Examples of current and future socio-cultural research (pertaining to managing emotions)

\begin{tabular}{ll}
\hline Level Existing research & Future research
\end{tabular}

Microsystem Loving-kindness meditation enhances workplace relationships (Fredrickson et al. 2008).

'Hopeful' leaders engender emotional resilience (Norman et al. 2005).

Mesosystem Emotional intelligence skills mitigate work-life conflict (Lenaghan et al. 2007).

Emotional intelligence skills enhance bonding between teams (Ajay and Akhilesh 2007).

Exosystem Social network analysis of the quality of network ties (Cross et al. 2002).

Organisation-wide implementation of mindfulness-based interventions (e.g., Lancashire Care NHS Foundation Trust 2015).

Macrosystem National data on subjective wellbeing (Office for National Statistics 2011).

Wellbeing-driven policy initiatives (Bache and Reardon 2013).

Ecosystem The impact of mindfulness on ecological awareness (Jacob et al. 2009).

The wellbeing value of connection to nature (Gesler 1992).
The impact of mindfulness-based interventions and emotional intelligence interventions on communication patterns among co-workers.

The impact of resilience interventions on team performance.

The association between social capital and employee resilience.

The impact of mindfulness-based interventions on work-life conflict.

The impact of emotional intelligence training on inter-department co-operation.

Organisation-level (e.g., entire NHS) randomised controlled trials of the impact of mindfulness-based interventions on health, wellbeing, and performance-related outcomes.

Impact of systemic processes (e.g., mechanisms for inter-departmental interaction) on employee resilience and PsyCap.

Assessment of the impact of national guidelines on the use of emotional management training (e.g., mindfulness-based interventions) in workplaces.

Surveys of the current state of emotion-based training offered by employers nationwide.

The impact of emotional intelligence on pro-environmental behaviour among employees and by the organisation as a whole.

The impact of 'mindfulness of nature' interventions on environmental attitudes and behaviour. 


\subsubsection{Mesosystem}

The mesosystem refers to the interaction between microsystems. In a work context, this could be construed in various ways. In an organisation, the relationship between different teams or departments is a mesosystemic phenomenon, as is the interaction between the organisation itself and other organisations. The relationship between a person's work and home life - captured in the notion of 'work-life balance,' part of the 'workload and scheduling' driver - is also a mesosystemic process. In terms of ME, as with the microsystem, we can firstly consider its impact on these mesosystemic processes. There are indications that emotional intelligence skills can mitigate mesosystemic conflict, such as work-life issues (Lenaghan et al. 2007), and facilitate mesosystemic bonding, such as between different teams or departments within an organisation (Ajay and Akhilesh 2007). Conversely, from a top-down direction, mesosystemic processes impact on ME. Mesosystemic conflicts, such as work-life issues, are a source of stress, adversely affecting people's ability to manage their emotions (Hobson et al. 2001). For this reason, Hobson et al. argue for corporate initiatives to help deal with work-life conflict. Indeed, the importance of such initiatives has been recognised at a macrosystemic level by the UK government, which launched a consultation on flexible working rights in 2011, concluding that it generally enhanced outcomes such as productivity and retention (Smeaton et al. 2014). In terms of persuading organisations to invest in such projects, this is helped by case studies of corporations like IBM, which have shown that flexible working arrangements (e.g., telecommuting) have saved millions of dollars, due to factors such as enhanced retention (e.g., the Chartered Institute of Personnel and Development (2011a) estimated the average turnover cost per employee to be $£ 8200$ ), and reduced energy costs (Caldow 2009).

\subsubsection{Exosystem}

The exosystem refers to the wider 'social structures' that 'impinge upon or encompass' the microsystems (Bronfenbrenner 1977, p.515). In an occupational context, we might regard this as the broader organisation that encompasses any microsystemic workplace. In terms of $\mathrm{ME}$, the dynamics are somewhat different to that of the microsystem and mesosystem: the exosystem is more structural and diffuse; it is therefore harder for employees' emotional management skills to impact directly upon the system. That said, we can of course still analyse the impact of emotion management at an exosystem level. For instance, as noted above, the Mindful Nation (2015) report recommended that public bodies such as the NHS implement mindfulness training for their employees, and also advocated the implementation of large scale research trials. It would be conceivable and indeed desirable to combine these two recommendations. The health service could enact an extensive yet selective implementation of mindfulness-based interventions among its workforce, such that only certain regions or trusts implemented it at first, with the remainder serving as 'wait-list' controls. It would then be possible to examine the impact of mindfulness training on a panoply of outcomes, from occupational health to job performance. Such initiatives would also highlight the impact of exosystemic processes on ME, since the very implementation of mindfulness training would be being driven at an exosystem level. Indeed, these types of exosystemic wellbeing initiatives are increasingly common. For instance, following the publication of the 'Healthy Staff' policy paper by the Department of Health (2011), the NHS has 
been working towards engendering better staff wellbeing, including through mindfulness (e.g., Lancashire Care NHS Foundation Trust 2015).

\subsubsection{Macrosystem}

The macrosystem refers to overarching processes - 'economic, social, educational, legal, and political systems' (Bronfenbrenner 1977, p.515) - that influence the three preceding levels. Indeed, as has been intimated throughout, this level exerts a powerful top-down effect on the drivers of wellbeing generally, and ME in particular. For instance, as seen above with the exosystem, efforts by bodies like the NHS to implement systemic wellbeing programmes for staff have been partly driven by policy initiatives such as the Department of Health's (2011) 'Healthy Staff' model. Indeed, this policy paper reflects a wider concern at a political level in the United Kingdom with a wellbeing-driven policy agenda. This is reflected in various initiatives, such as the creation of a National Wellbeing Index, involving data on subjective wellbeing gathered by the Office for National Statistics (2011) as part of its Integrated Household Survey, with the stated intention that this index would help guide governmental decisions (Bache and Reardon 2013). Since then, a raft of other macrosystemic initiatives have likewise emerged to help deliver evidence-driven policy pertaining to wellbeing. For instance, as part of the government's 'What Works' network, Public Health England helped to establish a 'What Works Centre for Wellbeing' in 2014 cited above in relation to the Mindful Nation report - with a remit to commission research into the impact of interventions and services upon wellbeing. This includes a 'Work, Learning and Wellbeing' programme aimed at workers, adult learners and job seekers. This kind of initiative can help drive forward the type of research outlined above, exploring the ways ME impacts on wellbeing (and indeed analysing the impact of all the drivers). Moreover, given the need for policy to be evidence-driven, such initiatives do not only serve an important analytic role, but are themselves a key force behind the provision of wellbeing interventions. This reinforces the point that the drivers are influenced by processes occurring at all dimensions and levels of the LIFE model.

\subsubsection{Ecosystem}

To finish, it is worth briefly touching upon the ecosystem (i.e., the global biosphere that encompasses even macrosystemic processes). This level is included in the LIFE model because not only do environmental factors (e.g., pollution levels) influence wellbeing, but in an existential sense, human wellbeing is ultimately dependent upon planetary wellbeing (Smith et al. 2013). While it might appear that this level has little relevance to $\mathrm{ME}$ in a work context, there are relevant considerations and analyses. For instance, in terms of the impact of humans on the environment, one of the biggest factors is the behaviour of corporations (e.g., polluting behaviours by industrial manufacturers). One might conceivably explore the impact of emotion management training on environmental awareness and pro-environmental behaviour; indeed, practices like mindfulness have been associated with just these types of outcomes (Jacob et al. 2009). As humanity begins to come to terms with the challenges posed by climate change, these types of considerations will be increasingly important. 


\subsection{Summary}

This paper has sought to bring a multidimensional perspective to bear on the workrelated drivers of wellbeing. It had two main aims: (a) to provide a multidimensional overview of the drivers; (b) and to illustrate how we could analyse these drivers in a multidimensional way. The first part of the paper provided the overview. After consulting prominent taxonomies, 11 drivers were identified, which were aggregated into three broad categories: psychological drivers (deploying strengths, managing emotions, aligning purpose, and personal and professional development); physical drivers (health and safety, work load and scheduling, and job content and control); and socio-cultural drivers (relationships, leadership, values, and reward and recognition). Part 2 then sought to show what a multidimensional analysis of these drivers might look like. It did this by focusing on one particular driver - managing emotions - as a case study. It analysed this through the prism of the LIFE model, which identifies four dimensions to the person, with each dimension stratified into five layers. Thus managing emotions was examined in terms of how it impacts upon, and is impacted by, the psychological dimension (comprising embodiment, emotions, cognitions, consciousness, and awareness+), the physical dimension (comprising biochemistry, neurons, neural networks, the nervous system, and the body as a whole), and the socio-cultural dimensions (aggregated together, comprising micro-, meso-, exo-, macro-, and ecosystems). Consequently, the paper offers a generative future research agenda - in which this type of analysis might be applied to all the other drivers - thereby allowing us to further understand the work-related drivers of wellbeing, and helping people to better flourish at work.

\section{Compliance with Ethical Standards}

Conflict of Interest The author states that there is no conflict of interest.

\section{References}

Ajay, G., \& Akhilesh, K. B. (2007). Interplay among innovativeness, cognitive intelligence, emotional intelligence and social capital of work teamsnull. Team Performance Management: An International Journal, 13(7/8), 206-226. https://doi.org/10.1108/13527590710842538.

American Psychological Association (APA) (1999). What is a psychologically healthy workplace? Retreived on 10 December 2015 from http:/www.apahelpcenter.org/articles/article.php?id=34.

Appleton, A., Loucks, E., Buka, S., \& Kubzansky, L. (2014). Divergent associations of antecedent- and response-focused emotion regulation strategies with midlife cardiovascular disease risk. Annals of Behavioral Medicine, 48(2), 246-255. https://doi.org/10.1007/s12160-014-9600-4.

Avolio, B. J., \& Gardner, W. L. (2005). Authentic leadership development: Getting to the root of positive forms of leadership. The Leadership Quarterly, 16(3), 315-338. https://doi.org/10.1016/j. leaqua.2005.03.001.

Bache, I., \& Reardon, L. (2013). An idea whose time has come? Explaining the rise of well-being in British politics. Political Studies, 61(4), 898-914. https://doi.org/10.1111/1467-9248.12001.

Bakker, A. B., \& Schaufeli, W. B. (2008). Positive organizational behavior: Engaged employees in flourishing organizations. Journal of Organizational Behavior, 29(2), 147-154. https://doi.org/10.1002/job.515. 
Bambra, C., Egan, M., Thomas, S., Petticrew, M., \& Whitehead, M. (2007). The psychosocial and health effects of workplace reorganisation. 2. A systematic review of task restructuring interventions. Journal of Epidemiology and Community Health, 61(12), 1028-1037. https://doi.org/10.1136/jech.2006.054999.

Barrett, L. F., Gross, J., Christensen, T. C., \& Benvenuto, M. (2001). Knowing what you're feeling and knowing what to do about it: Mapping the relation between emotion differentiation and emotion regulation. Cognition \& Emotion, 15(6), 713-724. https://doi.org/10.1080/02699930143000239.

Bartol, K. M., \& Srivastava, A. (2002). Encouraging knowledge sharing: The role of organizational reward systems. Journal of Leadership and Organizational Studies, 9(1), 64-76. https://doi.org/10.1177 /107179190200900105.

Basner, M., Babisch, W., Davis, A., Brink, M., Clark, C., Janssen, S., \& Stansfeld, S. (2014). Auditory and non-auditory effects of noise on health. Lancet, 383(9925), 1325-1332. https://doi.org/10.1016/S01406736(13)61613-X.

Bass, B. M. (1991). From transactional to transformational leadership: Learning to share the vision. Organizational Dynamics, 18(3), 19-31. https://doi.org/10.1016/0090-2616(90)90061-S.

Baumeister, R. F., \& Vohs, K. D. (2003). Self-regulation and the executive function of the self. In M. R. Leary \& J. P. Tangney (Eds.), Handbook of self and identity (pp. 197-217). New York: Guilford Press.

Beck, D. E., \& Cowan, C. (1996). Spiral dynamics: Mastering values, leadership and change. Cambridge: Blackwell.

Beck, A. T., Rush, A. J., Shaw, B. F., \& Emery, G. (1979). Cognitive therapy of depression. New York: Guilford.

Bellah, R. N., Madsen, R., Sullivan, W. M., Swidler, A., \& Tipton, S. M. (1996). Habits of the heart: Individualism and commitment in American life. Berkeley: University of California Press.

Bernardes Souza, B., Mussi Monteze, N., Pereira de Oliveira, F. L., de Oliveira, J. M., Nascimento de Freitas, S., Marques do Nascimento Neto, R., et al. (2014). Lifetime shift work exposure: Association with anthropometry, body composition, blood pressure, glucose and heart rate variability. Occupational and Environmental Medicine. https://doi.org/10.1136/oemed-2014-102429.

Bernerth, J. B., Armenakis, A. A., Feild, H. S., Giles, W. F., \& Walker, H. J. (2007). Leader-member social exchange (LMSX): Development and validation of a scale. Journal of Organizational Behavior, 28(8), 979-1003. https://doi.org/10.1002/job.443.

Bond, F. W., Flaxman, P. E., \& Bunce, D. (2008). The influence of psychological flexibility on work redesign: Mediated moderation of a work reorganization intervention. The Journal of Applied Psychology, 93(3), 645-654. https://doi.org/10.1037/0021-9010.93.3.645.

Bourdieu, P. (1986). The forms of capital. In J. G. Richardson (Ed.), Handbook of theory and research for the sociology of education (pp. 241-258). New York: Greenwood.

Bowling, N. A., Eschleman, K. J., Wang, Q., Kirkendall, C., \& Alarcon, G. (2010). A meta-analysis of the predictors and consequences of organization-based self-esteem. Journal of Occupational and Organizational Psychology, 83(3), 601-626. https://doi.org/10.1348/096317909X454382.

Brani, O., Hefferon, K., Lomas, T., Ivtzan, I., \& Painter, J. (2014). The impact of body awareness on subjective wellbeing: The role of mindfulness. International Journal of Body Psychotherapy, 13(1), 94-107.

Brewer, S., Van Eerd, D., Amick, B. C., III, Irvin, E., Daum, K. M., Gerr, F., et al. (2006). Workplace interventions to prevent musculoskeletal and visual symptoms and disorders among computer users: a systematic review. Journal of Occupational Rehabilitation, 16(3), 317-350.

Bronfenbrenner, U. (1977). Toward an experimental ecology of human development. The American Psychologist, 32(7), 513-531. https://doi.org/10.1037/0003-066X.32.7.513.

Brown, M. E., Trevino, L. K., \& Harrison, D. A. (2005). Ethical leadership: A social learning perspective for construct development and testing. Organizational Behavior and Human Decision Processes, 97(2), 117134. https://doi.org/10.1016/j.obhdp.2005.03.002.

Brown, K. W., Ryan, R. M., \& Creswell, J. D. (2007). Mindfulness: Theoretical foundations and evidence for its salutary effects. Psychological Inquiry, 18(4), 211-237. https://doi.org/10.1080/10478400701598298.

Caldow, J. (2009). Working outside the box: A study of the growing momentum in telework. New York: Institute for Electronic Government, IBM Corporation.

Cameron, K. S., Dutton, J. E., \& Quinn, R. E. (2003). Foundations of positive organizational scholarship. In K. S. Cameron, J. E. Dutton, \& R. E. Quinn (Eds.), Positive organizational scholarship: Foundations of a new discipline (pp. 3-13). San Francisco: Berrett-Koehler. 
Chambers, R., Gullone, E., \& Allen, N. B. (2009). Mindful emotion regulation: An integrative review. Clinical Psychology Review, 29(6), 560-572. https://doi.org/10.1016/j.cpr.2009.06.005.

Chartered Institute of Personnel and Development. (2011a). A barometer of HR trends and prospects 2011. London: Chartered Institute of Personnel and Development.

Chartered Institute of Personnel and Development. (2011b). Developing resilience: An evidence-based guide for practitioners. London: Chartered Institute of Personnel and Development.

Clark, S. C. (2000). Work/family border theory: A new theory of work/family balance. Human Relations, 53(6), 747-770. https://doi.org/10.1177/0018726700536001.

Coetzer, A., Redmond, J., \& Bastian, V. (2014). Strength-based coaching: Making the case for its adoption in small businesses. Development and Learning in Organizations: An International Journal, 28(3), 6-9.

Collins, D. B., \& Holton, E. F. (2004). The effectiveness of managerial leadership development programs: A meta-analysis of studies from 1982 to 2001. Human Resource Development Quarterly, 15(2), 217-248. https://doi.org/10.1002/hrdq.1099.

Cook-Greuter, S. R. (2000). Mature ego development: A gateway to ego transcendence? Journal of Adult Development, 7(4), 227-240.

Cooperrider, D. L., \& Srivastva, S. (1987). Appreciative inquiry in organizational life. Research in Organizational Change and Development, 1(1), 129-169.

Côté, S., \& Morgan, L. M. (2002). A longitudinal analysis of the association between emotion regulation, job satisfaction, and intentions to quit. Journal of Organizational Behavior, 23(8), 947-962. https://doi. org/10.1002/job.174.

Crabb, S. (2011). The use of coaching principles to foster employee engagement. The Coaching Psychologist, $7(1), 27-34$.

Cross, R., Borgatti, S. P., \& Parker, A. (2002). Making invisible work visible: Using social network analysis to support strategic collaboration. California Management Review, 44(2), 25-46. https://doi.org/10.2307 /41166121.

Csikszentmihalyi, M. (1990). Flow: The psychology of optimal experience. New York: Harper Perennial.

da Costa, B. R., \& Vieira, E. R. (2008). Stretching to reduce work-related musculoskeletal disorders: A systematic review. Journal of Rehabilitation Medicine, 40(5), 321-328. https://doi.org/10.2340 /16501977-0204.

Daltroy, L. H., Iversen, M. D., Larson, M. G., Lew, R., Wright, E., Ryan, J., et al. (1997). A controlled trial of an educational program to prevent low back injuries. The New England Journal of Medicine, 337(5), 322-328. https://doi.org/10.1056/NEJM199707313370507.

Daniels, K., Karanika-Murray, M., Mellor, N., \& van Veldhoven, M. (2012). Moving policy and practice forward. In C. Biron, M. Karanika-Murray, \& C. L. Cooper (Eds.), Improving organizational interventions for stress and well-being: Addressing process and context (pp. 313-332). London: Routledge.

Davidson, R. J. (2003). Affective neuroscience and psychophysiology: Toward a synthesis. Psychophysiology, 40(5), 655-665. https://doi.org/10.1111/1469-8986.00067.

Davidson, R. J., Kabat-Zinn, J., Schumacher, J., Rosenkranz, M., Muller, D., Santorelli, S. F., et al. (2003). Alterations in brain and immune function produced by mindfulness meditation. Psychosomatic Medicine, 65(4), 564-570. https://doi.org/10.1097/01.psy.0000077505.67574.e3.

De Cremer, D., van Knippenberg, B., van Knippenberg, D., Mullenders, D., \& Stinglhamber, F. (2005). Rewarding leadership and fair procedures as determinants of self-esteem. The Journal of Applied Psychology, 90(1), 3-12. https://doi.org/10.1037/0021-9010.90.1.3.

Deci, E. L., Connell, J. P., \& Ryan, R. M. (1989). Self-determination in a work organization. The Journal of Applied Psychology, 74(4), 580-590. https://doi.org/10.1037/0021-9010.74.4.580.

Delaney, J. T., \& Sockell, D. (1992). Do company ethics training programs make a difference? An empirical analysis. Journal of Business Ethics, 11(9), 719-727.

Demerouti, E., Bakker, A. B., Nachreiner, F., \& Schaufeli, W. B. (2001). The job demands-resources model of burnout. The Journal of Applied Psychology, 86(3), 499-512.

Department of Health. (2011). Healthy staff, better Care for Patients: Realignment of occupational health services to the NHS in England. London: Department of Health.

Dik, B. J., Duffy, R. D., \& Eldridge, B. M. (2009). Calling and vocation in career counseling: Recommendations for promoting meaningful work. Professional Psychology: Research and Practice, 40(6), 91-127. https://doi.org/10.1037/a0015547. 
Dik, B. J., Steger, M. F., Gibson, A., \& Peisner, W. (2011). Make your work matter: Development and pilot evaluation of a purpose-centered career education intervention. New Directions for Youth Development, 132, 59-73. https://doi.org/10.1002/yd.428.

Dragesund, T., \& Råheim, M. (2008). Norwegian psychomotor physiotherapy and patients with chronic pain: Patients' perspective on body awareness. Physiotherapy Theory and Practice, 24(4), 243-254. https://doi. org/10.1080/09593980701738400.

Dutton, J. E., Roberts, L. M., \& Bednar, J. (2010). Pathways for positive identity construction at work: Four types of positive identity and the building of social resources. The Academy of Management Review, 35(2), 265-293. https://doi.org/10.5465/amr.35.2.zok265.

Elbogen, E. B., Johnson, S. C., Newton, V. M., Timko, C., Vasterling, J. J., Van Male, L. M., et al. (2014). Protective mechanisms and prevention of violence and aggression in veterans. Psychological Services, 11(2), 220-228.

Fell, J. (2004). Identifying neural correlates of consciousness: The state space approach. Consciousness and Cognition, 13(4), 709-729. https://doi.org/10.1016/j.concog.2004.07.001.

Fillion, L., Duval, S., Dumont, S., Gagnon, P., Tremblay, I., Bairati, I., \& Breitbart, W. S. (2009). Impact of a meaning-centered intervention on job satisfaction and on quality of life among palliative care nurses. Psycho-Oncology, 18(12), 1300-1310. https://doi.org/10.1002/pon.1513.

Forest, J., Mageau, G. A., Crevier-Braud, L., Bergeron, É., Dubreuil, P., \& Lavigne, G. L. (2012). Harmonious passion as an explanation of the relation between signature strengths' use and well-being at work: Test of an intervention program. Human Relations, 65(9), 1233-1252. https://doi.org/10.1177 /0018726711433134.

Fredrickson, B. L., Cohn, M. A., Coffey, K. A., Pek, J., \& Finkel, S. M. (2008). Open hearts build lives: Positive emotions, induced through loving-kindness meditation, build consequential personal resources. Journal of Personality and Social Psychology, 95(5), 1045-1062. https://doi. org/10.1037/a0013262.

Fry, L. W. (2003). Toward a theory of spiritual leadership. The Leadership Quarterly, 14(6), 693-727. https://doi.org/10.1016/j.leaqua.2003.09.001.

Fullagar, C. J., \& Kelloway, E. K. (2009). Flow at work: An experience sampling approach. Journal of occupational and organizational psychology, 82(3), 595-615. https://doi.org/10.1348/096317908 X357903

Garriga, E., \& Melé, D. (2004). Corporate social responsibility theories: Mapping the territory. Journal of Business Ethics, 53(1-2), 51-71. https://doi.org/10.1023/B:BUSI.0000.

Gesler, W. M. (1992). Therapeutic landscapes: Medical issues in light of the new cultural geography. Social Science \& Medicine, 34(7), 735-746. https://doi.org/10.1016/0277-9536(92)90360-3.

Giordano, F. G. (1995). The whole person at work: An integrative vocational intervention model for women's workplace issues. The Journal for Specialists in Group Work, 20(1), 4-13. https://doi.org/10.1080 /01933929508411319.

Good, D. J., Lyddy, C. J., Glomb, T. M., Bono, J. E., Brown, K. W., Duffy, M. K., et al. (2015). Contemplating mindfulness at work: An integrative review. Journal of Management, 42(1), 114-142. https://doi. org/10.1177/0149206315617003.

Gourzoulidis, G., Kontodimopoulos, N., Kastanioti, C., Bellali, T., Goumas, K., Voudigaris, D., \& Polyzos, N. (2014). Do self-perceptions of emotional intelligence predict health-related quality of life? A case study in hospital managers in Greece. Global Journal of Health Science, 7(1), 210-219. https://doi.org/10.5539 /gjhs.v7n1p210.

Grant, D. (2004). Spiritual interventions: How, when, and why nurses use them. Holistic Nursing Practice, $18(1), 36-41$.

Gronn, P. (2000). Distributed properties a new architecture for leadership. Educational Management Administration \& Leadership, 28(3), 317-338.

Gross, J. J. (1999). Emotion regulation: Past, present, future. Cognition \& Emotion, 13(5), 551-573. https://doi.org/10.1080/026999399379186.

Haase, L., May, A. C., Falahpour, M., Isakovic, S., Simmons, A. N., Hickman, S. D., et al. (2015). A pilot study investigating changes in neural processing after mindfulness training in elite athletes. Frontiers in Behavioral Neuroscience, 9, 229. https://doi.org/10.3389/fnbeh.2015.00229.

Hahn, R. A., \& Truman, B. I. (2015). Education improves public health and promotes health equity. International Journal of Health Services, 45(4), 657-678. https://doi.org/10.1177/0020731415585986. 
Hätinen, M., Kinnunen, U., Pekkonen, M., \& Kalimo, R. (2007). Comparing two burnout interventions: Perceived job control mediates decreases in burnout. International Journal of Stress Management, 14(3), 227-248. https://doi.org/10.1037/1072-5245.14.3.227.

Hayes, B. E., Perander, J., Smecko, T., \& Trask, J. (1998). Measuring perceptions of workplace safety: Development and validation of the work safety scale. Journal of Safety Research, 29(3), 145-161. https://doi.org/10.1016/S0022-4375(98)00011-5.

Hayhurst, E. R. (1915). The prevalence of occupational factors in disease and suggestions for their elimination: Results of a study conducted at the central free dispensary (Rush medical college) and Cook County Hospital, Chicago. American Journal of Public Health, 5(6), 538-550.

Health and Safety Executive (1998). The working time regulations 1998. Retreived retreived on 10 December $2015 \mathrm{http} / /$ www.hse.gov.uk/contact/faqs/workingtimedirective.htm

Herbert, B. M., Herbert, C., \& Pollatos, O. (2011). On the relationship between interoceptive awareness and alexithymia: Is interoceptive awareness related to emotional awareness? Journal of Personality, 79(5), 1149-1175. https://doi.org/10.1111/j.1467-6494.2011.00717.x.

Hobson, C. J., Delunas, L., \& Kesic, D. (2001). Compelling evidence of the need for corporate work/life balance initiatives: Results from a national survey of stressful life-events. Journal of Employment Counseling, 38(1), 38-44. https://doi.org/10.1002/j.2161-1920.2001.tb00491.x.

Holman, D., Chissick, C., \& Totterdell, P. (2002). The effects of performance monitoring on emotional labor and well-being in call centers. Motivation and Emotion, 26(1), 57-81. https://doi.org/10.1023 /A:1015194108376.

House, R. J. (1977). A 1976 theory of charismatic leadership. In J. G. Hunt \& L. L. Larson (Eds.), Leadership: The cutting edge (pp. 189-207). Carbondale: Southern Illinois University Press.

Jackson, D., Firtko, A., \& Edenborough, M. (2007). Personal resilience as a strategy for surviving and thriving in the face of workplace adversity: A literature review. Journal of Advanced Nursing, 60(1), 1-9. https://doi.org/10.1111/j.1365-2648.2007.04412.x.

Jacob, J., Jovic, E., \& Brinkerhoff, M. B. (2009). Personal and planetary well-being: Mindfulness meditation, pro-environmental behavior and personal quality of life in a survey from the social justice and ecological sustainability movement. Social Indicators Research, 93(2), 275-294. https://doi.org/10.1007/s11205008-9308-6.

Josipovic, Z. (2010). Duality and nonduality in meditation research. Consciousness and Cognition, 19(4), 1119-1121. https://doi.org/10.1016/j.concog.2010.03.016.

Kabat-Zinn, J. (2003). Mindfulness-based interventions in context: Past, present, and future. Clinical Psychology: Science and Practice, 10(2), 144-156. https://doi.org/10.1093/clipsy.bpg016.

Kandolin, I., \& Huida, O. (1996). Individual flexibility: An essential prerequisite in arranging shift schedules for midwives. Journal of Nursing Management, 4(4), 213-217. https://doi.org/10.1046/j.13652834.1996.02174.x.

Karimi, L., Cheng, C., Bartram, T., Leggat, S. G., \& Sarkeshik, S. (2015). The effects of emotional intelligence and stress-related presenteeism on nurses' well-being. Asia-Pacific Journal of Human Resources, 53(3), 296-310. https://doi.org/10.1111/1744-7941.12049.

Kellogg, R. T. (2008). Training writing skills: A cognitive developmental perspective. Journal of Writing Research, 1(1), 1-26.

Kennedy, C. A., Amick, B. C., III, Dennerlein, J. T., Brewer, S., Catli, S., Williams, R., et al. (2010). Systematic review of the role of occupational health and safety interventions in the prevention of upper extremity musculoskeletal symptoms, signs, disorders, injuries, claims and lost time. Journal of Occupational Rehabilitation, 20(2), 127-162. https://doi.org/10.1007/s10926-009-9211-2.

Kets de Vries, M. F. R. (2001). Creating authentizotic organizations: Well-functioning individuals in vibrant companies. Human Relations, 54(1), 101-111.

Koenig, H. G. (2013). Spirituality in patient care: Why, how, when, and what. New York: Templeton Foundation Press.

Kohlberg, L. (1981). The philosophy of moral development: Moral stages and the idea of justice. London: Harper \& Row.

Kreiner, G. E. (2006). Consequences of work-home segmentation or integration: A person-environment fit perspective. Journal of Organizational Behavior, 27(4), 485-507. https://doi.org/10.1002/job.386.

Kruijver, I. P., Kerkstra, A., Francke, A. L., Bensing, J. M., \& van de Wiel, H. B. (2000). Evaluation of communication training programs in nursing care: A review of the literature. Patient Education and Counseling, 39(1), 129-145. https://doi.org/10.1016/S0738-3991(99)00096-8. 
Laborde, S., Lautenbach, F., Allen, M. S., Herbert, C., \& Achtzehn, S. (2014). The role of trait emotional intelligence in emotion regulation and performance under pressure. Personality and Individual Differences, 57, 43-47. https://doi.org/10.1016/j.paid.2013.09.013.

Lana, A., Baizán, E. M., Faya-Ornia, G., \& López, M. L. (2015). Emotional intelligence and health risk behaviors in nursing students. The Journal of Nursing Education, 54(8), 464 467. https://doi.org/10.3928 /01484834-20150717-08.

Lancashire Care NHS Foundation Trust. (2015). Mindfulness-based cognitive therapy improves staff wellbeing. Lancashire: NHS Northwest.

Leiter, M. P., Laschinger, H. K. S., Day, A., \& Oore, D. G. (2011). The impact of civility interventions on employee social behavior, distress, and attitudes. The Journal of Applied Psychology, 96(6), 1258-1274. https://doi.org/10.1037/a0024442.

Lenaghan, J. A., Buda, R., \& Eisner, A. B. (2007). An examination of the role of emotional intelligence in work and family conflict. Journal of Managerial Issues, 19(1), 76-94.

Levering, R. (1988). A great place to work. New York: Avon Books.

Linley, P. A., Woolston, L., \& Biswas-Diener, R. (2009). Strengths coaching with leaders. International Coaching Psychology Review, 4(1), 37-48.

Logan, M. S., \& Ganster, D. C. (2005). An experimental evaluation of a control intervention to alleviate jobrelated stress. Journal of Management, 31(1), 90-107. https://doi.org/10.1177/0149206304271383.

Loisel, P., Lemaire, J., Poitras, S., Durand, M.-J., Champagne, F., Stock, S., et al. (2002). Cost-benefit and cost-effectiveness analysis of a disability prevention model for back pain management: A six year follow up study. Occupational and Environmental Medicine, 59(12), 807-815. https://doi.org/10.1136 /oem.59.12.807.

Lomas, T. (2015a). Positive social psychology: A multilevel inquiry into socio-cultural wellbeing initiatives. Psychology, Public Policy, and Law, 21(3), 338-347. https://doi.org/10.1037/law0000051 .

Lomas, T. (2015b). Self-transcendence through shared suffering: A transpersonal theory of compassion. Journal of Transpersonal Psychology, 27(2), 168-187.

Lomas, T., Edginton, T., Cartwright, T., \& Ridge, D. (2014). Men developing emotional intelligence through meditation? Combining narrative, cognitive, and electroencephalography (EEG) evidence. Psychology of Men \& Masculinity, 15(2), 213-224. https://doi.org/10.1037/a0032191.

Lomas, T., Hefferon, K., \& Ivtzan, I. (2015a). The LIFE model: A meta-theoretical conceptual map for applied positive psychology. Journal of Happiness Studies, 16(5), 1347-1364. https://doi.org/10.1007/s10902014-9563-y.

Lomas, T., Ivtzan, I., \& Fu, C. (2015b). A systematic review of the neurophysiology of mindfulness on EEG oscillations. Neuroscience and Biobehavioral Reviews, 57, 401-410. https://doi.org/10.1016/j. neubiorev.2015.09.018.

Lomas, T., Medina, J. C., Ivtzan, I., Rupprecht, S., \& Eiroa-Orosa, F. J. (2017a). The impact of mindfulness on the wellbeing and performance of educators: A systematic review of the empirical literature. Teaching and Teacher Education, 61, 132-141. https://doi.org/10.1016/j.tate.2016.10.008

Lomas, T., Medina, J. C., Ivtzan, I., Rupprecht, S., Hart, R., \& Eiroa-Orosa, F. J. (2017b). The impact of mindfulness on wellbeing and performance in the workplace: An inclusive systematic review of the empirical literature. European Journal of Work and Organizational Psychology, 26(4), 492-513. https://doi.org/10.1080/1359432X.2017.1308924.

Lomas, T., Medina, J. C., Ivtzan, I., Rupprecht, S., \& Eiroa-Orosa, F. J. (2018a). A systematic review and meta-analysis of the impact of mindfulness-based interventions on the wellbeing of healthcare professionals. Mindfulness. https://doi.org/10.1007/s12671-018-1062-5

Lomas, T., Medina, J. C., Ivtzan, I., Rupprecht, S., \& Eiroa-Orosa, F. J. (2018b). A systematic review of the impact of mindfulness on the wellbeing of healthcare professionals. Journal of Clinical Psychology, 7(3), 319-355. https://doi.org/10.1002/jclp.22515

Lomas, T., Medina, J. C., Ivtzan, I., Rupprecht, S., \& Eiroa-Orosa, F. J. (2018c). Mindfulness-based interventions in the workplace: An inclusive systematic review and meta-analysis of their impact upon wellbeing. Journal of Positive Psychology. https://doi.org/10.1080/17439760.2018.1519588

Luria, G., \& Morag, I. (2012). Safety management by walking around (SMBWA): A safety intervention program based on both peer and manager participation. Accident; Analysis and Prevention, 45, 248-257. https://doi.org/10.1016/j.aap.2011.07.010.

Luthans, F. (2002). The need for and meaning of positive organizational behavior. Journal of Organizational Behavior, 23(6), 695-706. https://doi.org/10.1002/job.165. 
Luthans, F., Youssef, C. M., \& Avolio, B. J. (2007). Psychological capital. Oxford: Oxford University Press.

Luthans, F., Avey, J. B., Avolio, B. J., \& Peterson, S. J. (2010). The development and resulting performance impact of positive psychological capital. Human Resource Development Quarterly, 21(1), 41-67. https://doi.org/10.1002/hrdq.20034.

Malarkey, W. B., Jarjoura, D., \& Klatt, M. (2013). Workplace based mindfulness practice and inflammation: A randomized trial. Brain, Behavior, and Immunity, 27, 145-154. https://doi.org/10.1016/j.bbi.2012.10.009.

McCarthy, V., Perry, I. J., \& Greiner, B. A. (2014). Job control and ambulatory blood pressure. Scandinavian Journal of Work, Environment \& Health, 40(5), 457-464.

McCraty, R., Atkinson, M., \& Tomasino, D. (2003). Impact of a workplace stress reduction program on blood pressure and emotional health in hypertensive employees. Journal of Alternative and Complementary Medicine, 9(3), 355-369. https://doi.org/10.1089/107555303765551589.

Mehling, W. E., Gopisetty, V., Daubenmier, J., Price, C. J., Hecht, F. M., \& Stewart, A. (2009). Body awareness: Construct and self report measures. PLoS One, 4(5), e5614. https://doi.org/10.1371/journal. pone.0005614.

Mikolajczak, M. (2014). The impact of emotional intelligence on physical health. Personality and Individual Differences, 60(Supplement), S22. https://doi.org/10.1016/j.paid.2013.07.404.

Mindfulness All-Party Parliamentary Group (MAPPG). (2015). Mindful nation UK. London: Mindfulness All-Party Parliamentary Group.

Moreno-Jiménez, B., Mayo, M., Sanz-Vergel, A. I., Geurts, S., Rodríguez-Muñoz, A., \& Garrosa, E. (2009). Effects of work-family conflict on employees' well-being: The moderating role of recovery strategies. Journal of Occupational Health Psychology, 14(4), 427-440. https://doi.org/10.1037/a0016739.

Morris, D., Bakan, I., \& Wood, G. (2006). Employee financial participation: Evidence from a major UK retailer. Employee Relations, 28(4), 326-341. https://doi.org/10.1108/01425450610673394.

Nahrgang, J. D., Morgeson, F. P., \& Hofmann, D. A. (2011). Safety at work: A meta-analytic investigation of the link between job demands, job resources, burnout, engagement, and safety outcomes. The Journal of Applied Psychology, 96(1), 71-94.

National Health Service (2015). Mindfulness for mental wellbeing. Retrieved 7 December, 2015, from http://www.nhs.uk/conditions/stress-anxiety-depression/pages/mindfulness.aspx

Nelis, D., Quoidbach, J., Mikolajczak, M., \& Hansenne, M. (2009). Increasing emotional intelligence: (how) is it possible? Personality and Individual Differences, 47(1), 36-41. https://doi.org/10.1016/j. paid.2009.01.046.

Newberg, A. B., \& Iversen, J. (2003). The neural basis of the complex mental task of meditation: Neurotransmitter and neurochemical considerations. Medical Hypotheses, 61(2), 282-291. https://doi. org/10.1016/S0306-9877(03)00175-0.

Norman, S., Luthans, B., \& Luthans, K. (2005). The proposed contagion effect of hopeful leaders on the resiliency of employees and organizations. Journal of Leadership and Organizational Studies, 12(2), 5564. https://doi.org/10.1177/107179190501200205.

Office for National Statistics. (2011). Initial investigation into subjective well-being from the opinions survey. London: Office for National Statistics.

Ormandy, D., \& Ezratty, V. (2012). Health and thermal comfort: From WHO guidance to housing strategies. Energy Policy, 49, 116-121. https://doi.org/10.1016/j.enpol.2011.09.003.

Page, K., \& Vella-Brodrick, D. (2013). The working for wellness program: RCT of an employee well-being intervention. Journal of Happiness Studies, 14(3), 1007-1031. https://doi.org/10.1007/s10902-012-9366y.

Parker, C. P., Baltes, B. B., Young, S. A., Huff, J., Altmann, R., LaCost, H., \& Roberts, J. E. (2003). Relationships between psychological climate perceptions and work outcomes: A meta-analytic review. Journal of Organizational Behavior, 24, 389-416. https://doi.org/10.1002/job.198.

Patel, A. S., Farquharson, R., Carroll, D., Moore, A., Phillips, C. J., Taylor, R. S., \& Barden, J. (2012). The impact and burden of chronic pain in the workplace: A qualitative systematic review. Pain Practice, 12(7), 578-589. https://doi.org/10.1111/j.1533-2500.2012.00547.x.

Persson, D., Erlandsson, L.-K., Eklund, M., \& Iwarsson, S. (2001). Value dimensions, meaning, and complexity in human occupation-a tentative structure for analysis. Scandinavian Journal of Occupational Therapy, 8(1), 7-18. https://doi.org/10.1080/11038120119727.

Peterson, C., \& Park, N. (2006). Character strengths in organizations. Journal of Organizational Behavior, 27(8), 1149-1154. https://doi.org/10.1002/job.398. 
Peterson, C., \& Seligman, M. E. P. (2004). Character strengths and virtues: A handbook and classification. Washington, DC: American Psychological Association.

Pollard, E. L., \& Davidson, L. (2001). Foundations of child wellbeing action research in family and early childhood. Paris: UNESCO.

Pomaki, G., \& Maes, S. (2002). Predicting quality of work life: From work conditions to self-regulation. In E. Gullone \& R. Cummins (Eds.), The universality of subjective wellbeing indicators (Vol. 16, pp. 151-173). Netherlands: Springer.

Pryce, J., Albertsen, K., \& Nielsen, K. (2006). Evaluation of an open-Rota system in a Danish psychiatric hospital: A mechanism for improving job satisfaction and work-life balance. Journal of Nursing Management, 14(4), 282-288. https://doi.org/10.1111/j.1365-2934.2006.00617.x.

Rath, T. (2007). Strengths Finder 2.0. New York: Gallup Press.

Rego, A., \& Cunha, M. P. e. (2008). Authentizotic climates and employee happiness: Pathways to individual performance? Journal of Business Research, 61(7), 739-752. https://doi.org/10.1016/j. jbusres.2007.08.003.

Reid, D. (2011). Mindfulness and flow in occupational engagement: Presence in doing. Canadian Journal of Occupational Therapy, 78(1), 50-56. https://doi.org/10.2182/cjot.2011.78.1.7.

Reivich, K. J., Seligman, M. E., \& McBride, S. (2011). Master resilience training in the US Army. The American Psychologist, 66(1), 25-34. https://doi.org/10.1037/a0021897.

Ridley-Duff, R., \& Bennett, A. (2011). Towards mediation: Developing a theoretical framework to understand alternative dispute resolution. Industrial Relations Journal, 42(2), 106-123. https://doi.org/10.1111 j.1468-2338.2011.00614.x.

Robertson, I. T., Cooper, C. L., Sarkar, M., \& Curran, T. (2015). Resilience training in the workplace from 2003 to 2014: A systematic review. Journal of Occupational and Organizational Psychology, 88(3), 533562. https://doi.org/10.1111/joop.12120.

Robinson, D. A., \& Harvey, M. (2008). Global leadership in a culturally diverse world. Management Decision, 46(3), 466-480.

Rogoff, B. (1990). Apprenticeship in thinking: Cognitive development in social context. Oxford: Oxford University Press.

Rubin, M. S., \& Stone, R. K. (2010). Adapting the "managing by walking around" methodology as a leadership strategy to communicate a hospital-wide strategic plan. Journal of Public Health Management and Practice, 16(2), 162-166. https://doi.org/10.1097/PHH.0b013e3181c6b68a.

Rupashree, B., \& Shivganesh, B. (2010). Work-family enrichment as a mediator between organizational interventions for work-life balance and job outcomes. Journal of Managerial Psychology, 25(3), 274300. https://doi.org/10.1108/02683941011023749.

Ryff, C. D. (1989). Happiness is everything, or is it? Explorations on the meaning of psychological well-being. Journal of Personality and Social Psychology, 57(6), 1069-1081. https://doi.org/10.1037/00223514.57.6.1069.

Salovey, P., \& Mayer, J. D. (1990). Emotional intelligence. Imagination, Cognition and Personality, 9(3), 185-211. https://doi.org/10.2190/DUGG-P24E-52WK-6CDG.

Satish, U., Mendell, M. J., Shekhar, K., Hotchi, T., Sullivan, D., Streufert, S., \& Fisk, W. J. (2012). Is CO2 an indoor pollutant? Direct effects of low-to-moderate CO2 concentrations on human decision-making performance. Environmental Health Perspectives, 120(12), 1671-1677. https://doi.org/10.1289 /ehp.1104789.

Sauter, S. L., Murphy, L. R., \& Hurrell, J. J. (1990). Prevention of work-related psychological disorders: A national strategy proposed by the National Institute for Occupational Safety and Health (NIOSH). The American Psychologist, 45, 1146-1158. https://doi.org/10.1037/0003-066 X.45.10.1146.

Schmeichel, B. J. (2007). Attention control, memory updating, and emotion regulation temporarily reduce the capacity for executive control. Journal of Experimental Psychology. General, 136(2), 241-255. https://doi.org/10.1037/0096-3445.136.2.241.

Schroeder, D. M., \& Robinson, A. G. (2002). America's most successful export to Japan: Continuous improvement programmes. In J. Henry \& D. Mayle (Eds.), Managing innovation and change (pp. 230-242). London: Sage.

Schulz, P., Kirschbaum, C., Prüßner, J., \& Hellhammer, D. (1998). Increased free cortisol secretion after awakening in chronically stressed individuals due to work overload. Stress and Health, 14(2), 91-97. 
Shaw, W. S., Tveito, T. H., Geehern-Lavoie, M., Huang, Y.-H., Nicholas, M. K., Reme, S. E., et al. (2012). Adapting principles of chronic pain self-management to the workplace. Disability and Rehabilitation, 34(8), 694-703. https://doi.org/10.3109/09638288.2011.615372.

Silverman, M. (2004). Non-financial recognition: The Most effective of rewards. London: Institute for Employment Studies Research Network.

Silverstein, R. G., Brown, A.-C. H., Roth, H. D., \& Britton, W. B. (2011). Effects of mindfulness training on body awareness to sexual stimuli: Implications for female sexual dysfunction. Psychosomatic Medicine, 73(9), 817-825. https://doi.org/10.1097/PSY.0b013e318234e628.

Smeaton, D., Ray, K., \& Knight, G. (2014). Costs and benefits to business of adopting work life balance working practices: A literature review. London: Department for Business Innovation and Skills.

Smith, L. M., Case, J. L., Smith, H. M., Harwell, L. C., \& Summers, J. K. (2013). Relating ecoystem services to domains of human well-being: Foundation for a U.S. index. Ecological Indicators, 28(0), 79-90. https://doi.org/10.1016/j.ecolind.2012.02.032.

Stajkovic, A. D., \& Luthans, F. (1998). Self-efficacy and work-related performance: A meta-analysis. Psychological Bulletin, 124(2), 240.

Steger, M. F., Dik, B. J., \& Duffy, R. D. (2012). Measuring meaningful work: The work and meaning inventory (WAMI). Journal of Career Assessment, 20(3), 322-337. https://doi.org/10.1177 $/ 1069072711436160$.

Super, D. E. (1980). A life-span, life-space approach to career development. Journal of Vocational Behavior, 16(3), 282-298. https://doi.org/10.1016/0001-8791(80)90056-1.

Thach, E. C. (2002). The impact of executive coaching and 360 feedback on leadership effectiveness. Leadership and Organization Development Journal, 23(4), 205-214. https://doi.org/10.1108 /01437730210429070.

Tucker, P., Macdonald, I., Folkard, S., \& Smith, L. (1998). The impact of early and late shift changeovers on sleep, health, and well-being in 8- and 12-hour shift systems. Journal of Occupational Health Psychology, 3(3), 265-275. https://doi.org/10.1037/1076-8998.3.3.265.

Turner, B. S. (2001). Disability and the sociology of the body. In G. L. Albrecht, K. D. Seelman, \& M. Bury (Eds.), Handbook of Disability Studies (pp. 252-266). Thousand Oaks: Sage.

Urry, H. L., Nitschke, J. B., Dolski, I., Jackson, D. C., Dalton, K. M., Mueller, C. J., et al. (2004). Making a life worth living: Neural correlates of well-being. Psychological Science, 15(6), 367-372. https://doi. org/10.1111/j.0956-7976.2004.00686.x.

van der Doef, M., \& Maes, S. (1999). The Leiden quality of work questionnaire: Its construction, factor structure, and psychometric qualities. Psychological Reports, 85(3), 954-962. https://doi.org/10.2466 /pr0.1999.85.3.954.

Virgili, M. (2015). Mindfulness-based interventions reduce psychological distress in working adults: A metaanalysis of intervention studies. Mindfulness, 6(2), 326-337. https://doi.org/10.1007/s12671-013-0264-0.

Wagner, S., White, M., Schultz, I., Williams-Whitt, K., Koehn, C., Dionne, C., et al. (2015). Social support and supervisory quality interventions in the workplace: A stakeholder-centered best-evidence synthesis of systematic reviews on work outcomes. The International Journal of Occupational and Environmental Medicine, 6(4), 608-189. https://doi.org/10.15171/ijoem.2015.608.

Weiss, H. M. (2002). Deconstructing job satisfaction: Separating evaluations, beliefs and affective experiences. Human Resource Management Review, 12(2), 173-194. https://doi.org/10.1016/S1053-4822(02 )00045-1.

Wilber, K. (2000). Integral psychology. Boston: Shambhala.

Williams, F. M. K., \& Sambrook, P. N. (2011). Neck and back pain and intervertebral disc degeneration: Role of occupational factors. Best Practice \& Research. Clinical Rheumatology, 25(1), 69-79. https://doi. org/10.1016/j.berh.2011.01.007.

Winwood, P. C., Winefield, A. H., Dawson, D., \& Lushington, K. (2005). Development and validation of a scale to measure work-related fatigue and recovery: The occupational fatigue exhaustion/recovery scale (OFER). Journal of Occupational and Environmental Medicine, 47(6), 594-606. https://doi.org/10.1097 /01.jom.0000161740.71049.c4.

World Health Organization. (1948). Preamble to the constitution of the World Health Organization as adopted by the international health conference, New York, 19-22 June, 1946. Geneva: World Health Organization.

World Health Organization. (2008). Global strategy on occupational health for all: The way to health at work. Geneva: World Health Organization. 
Wrzesniewski, A. (2003). Finding positive meaning in work. In K. S. Cameron, J. E. Dutton, \& R. E. Quinn (Eds.), Positive organizational scholarship: Foundations of a new discipline (pp. 296-308). San Francisco: Berrett-Koehler.

Zimet, G. D., Dahlem, N. W., Zimet, S. G., \& Farley, G. K. (1988). The multidimensional scale of perceived social support. Journal of Personality Assessment, 52(1), 30-41.

Zohar, D., \& Luria, G. (2003). The use of supervisory practices as leverage to improve safety behavior: A cross-level intervention model. Journal of Safety Research, 34(5), 567-577. https://doi.org/10.1207 /s15327752jpa5201_2.

Zwetsloot, G., \& Pot, F. (2004). The business value of health management. Journal of Business Ethics, 55(2), 115-124. https://doi.org/10.1007/s10551-004-1895-9.

Publisher's Note Springer Nature remains neutral with regard to jurisdictional claims in published maps and institutional affiliations. 